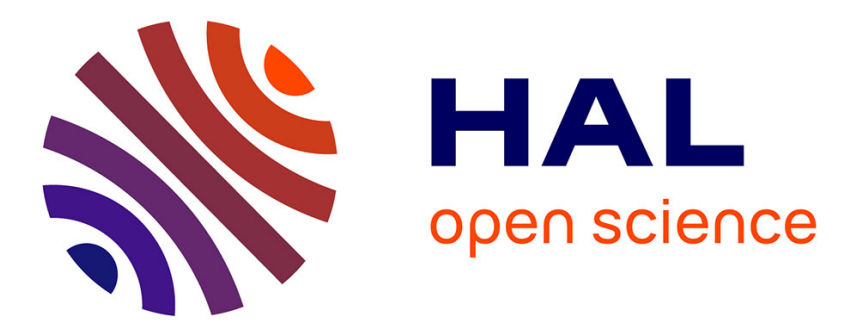

\title{
Up to $32 \%$ yield increase with optimized spatial patterns of canola plant establishment in western Canada
}

Chao Yang, Yantai Gan, K. Harker, H. Kutcher, Rob Gulden, Byron Irvine, William May

\section{To cite this version:}

Chao Yang, Yantai Gan, K. Harker, H. Kutcher, Rob Gulden, et al.. Up to $32 \%$ yield increase with optimized spatial patterns of canola plant establishment in western Canada. Agronomy for Sustainable Development, 2014, 34 (4), pp.793-801. 10.1007/s13593-014-0218-5 . hal-01234837

\section{HAL Id: hal-01234837 https://hal.science/hal-01234837}

Submitted on 27 Nov 2015

HAL is a multi-disciplinary open access archive for the deposit and dissemination of scientific research documents, whether they are published or not. The documents may come from teaching and research institutions in France or abroad, or from public or private research centers.
L'archive ouverte pluridisciplinaire $\mathbf{H A L}$, est destinée au dépôt et à la diffusion de documents scientifiques de niveau recherche, publiés ou non, émanant des établissements d'enseignement et de recherche français ou étrangers, des laboratoires publics ou privés. 


\title{
Up to $32 \%$ yield increase with optimized spatial patterns of canola plant establishment in western Canada
}

\author{
Chao Yang • Yantai Gan • K. Neil Harker • \\ H. Randy Kutcher • Rob Gulden • Byron Irvine • \\ William E. May
}

Accepted: 21 February 2014 / Published online: 26 March 2014

(C) INRA and Springer-Verlag France 2014

\begin{abstract}
Canola-Brassica napus L.- is an economically major crop in many parts of the world. The seed yield of canola is often limited by poor plant establishment. This issue is serious in areas with short growing seasons, such as western Canada, where canola plants have a limited time span plasticity to adapt and compensate for yield losses due to poor or non-uniform plant establishment. The effect of spatial patterns of canola plant stands on seed yield is actually unknown. Therefore, we studied the impacts of uniformity of plant stands on pod formation, seed set, and crop yield of canola. Field experiments were conducted at 16 site-years across the different soil-climatic zones of the Canadian prairies. At each site-year, the cultivar InVigor ${ }^{\circledR}$ 5440, a glufosinate-resistant hybrid, was sown at 100, 80, 60, 40, and 20 plants per square meter with uniform and non-uniform stands. We found that spatially uniform stands increased seed yield by up to $32 \%$ at
\end{abstract}

C. Yang $\cdot$ Y. Gan $(\bowtie)$

Agriculture and Agri-Food Canada, Swift Current,

Saskatchewan S9H 3X2, Canada

e-mail: gan@agr.gc.ca

\section{K. N. Harker}

Agriculture and Agri-Food Canada, Lacombe, Alberta T4L 1W1, Canada

H. R. Kutcher

University of Saskatchewan, Saskatoon, Saskatchewan S7N 5A8, Canada

R. Gulden

University of Manitoba, Winnipeg, Manitoba R3T 2N2, Canada

B. Irvine

Agriculture and Agri-Food Canada, Carman, Manitoba R0G 0J0, Canada

W. E. May

Agriculture and Agri-Food Canada, Indian Head, Saskatchewan S0G $2 \mathrm{~K} 0$, Canada low-yielding sites and by up to $20 \%$ at the high-yielding sites compared to non-uniform plant stands. This effect is mainly due to increased number of fertile pods. The yield increase was more pronounced with plant densities lower than 60 plants per square meter. Also, canola seed yield depended largely on plant survival during the hot summer and was less affected by the rate of seedling emergence. We conclude that canola yield can be increased by improving the uniformity of plant spatial distribution patterns in the field regardless of environmental conditions.

Keywords Plant density $\cdot$ Plant uniformity $\cdot$ Survival rate Fertile pods

\section{Introduction}

In nature, living organisms are typically distributed in different spatial patterns to optimize resource use (Legendre and Fortin 1989). In a plant community, spatial patterns can affect the community's establishment, structure, and functionalities by varying environmental stresses and resource availability and by altering interspecies competition or pest pressure (Ahmad et al. 2008). Therefore, spatial patterns in a plant community play an important role in many ecological events, such as community stability, interplant competition, diversity maintenance, and community productivity (Perry et al. 2002).

Performance of individual plants within a community largely depends on the level of competition for resources with their neighboring plants (Uriarte et al. 2004). When resources are limited or when the individuals are unevenly distributed within the community, competition for available resources can become severe as the number and size of nearby plants increase (Wilson and Tilman 1991). Agronomic performance of canola is a function of the availability of environmental resources (Gan et al. 2012). A uniform stand distribution 
within a plant community increases plant biomass and productivity compared with a non-uniform stand distribution due to the availability of resources such as light, soil water, and organic carbon (Jasso de Rodríguez et al. 2002; Pronk et al. 2007). Most previous studies on spatial patterns are based on natural ecosystems (Legendre and Fortin 1989), and the effect of spatial patterns on the productivity of field crops is limited. A few studies have shown that non-uniform spatial distribution of plant stands can negatively influence the grain yield of sorghum (Sorghum vulgare), wheat (Triticum aestivum), and maize (Zea mays) compared to uniform spatial patterns (Larson and Vanderlip 1994; Olsen et al. 2005; Tokatlidis and Koutroubas 2004). However, the effect of spatial uniformity on other economic crops, such as canola, remains largely unknown.

Canola is a major oilseed that ranks third worldwide after soybean (Glycine max L.) and palm (Homaledra heptathalama L.) (Al-Barrak 2006). In Canada, the production of canola has increased dramatically during the past 20 years. In 1990, approximately 2.5 million hectares of cropland were seeded to canola with a total production of 3.26 million tonnes; by 2012, the area seeded to canola has increased about three times with a production of 13.3 million tonnes annually (Canola Concil of Canada 2012). Canola productivity is influenced by environmental conditions and agronomic practices (Liu et al. 2014). For example, the seed yield of canola grown in the northern Great Plains of North America is often limited by high temperatures during the mid-summer (Kutcher et al. 2010), as high temperatures during canola flowering decrease canola seed set (Gan et al. 2004). Fall-sown canola usually has a non-uniform spatial pattern with low crop yield compared with early-spring sown canola (Angadi et al. 2003). However, the association of low productivity and non-uniform plant stands in canola is largely unknown, and the magnitude of yield improvement with improved stand uniformity has not been defined. With those questions in mind, a comprehensive field study at 16 site-years across western Canada was conducted with the objectives of determining: (i) the effects of canola stand uniformity on seed yield across various environmental conditions, and (ii) the relationship among fertile pods, seed set, plant survival to the hot summer, and seed yield in canola. The central hypothesis was that uniform plant stands increase canola seed yield through increased number of fertile pods and that such an effect interacts with environmental conditions.

\section{Materials and methods}

The experiment was carried out at 16 site-years across various soil-climatic zones of western Canada from 2010 to 2012 (Table 1) including Carman, Lacombe, Melfort, and Swift Current in 3 years; Brandon in 2010; Indian Head in 2011; and Morden in 2011 and 2012. Detailed soil properties were measured at each of the 16 site-years.

\subsection{Experimental design and plot management}

At each site-year, the experiment consisted of nine treatments that were arranged in a randomized, complete block design with four replicates. Treatments were five spatial-uniform plant densities $\left(100,80,60,40\right.$, and 20 plants $\left.\mathrm{m}^{-2}\right)$ and four non-uniform plant densities $\left(80,60,40\right.$, and 20 plants $\left.\mathrm{m}^{-2}\right)$. The plot size was $4 \mathrm{~m}$ wide and $12 \mathrm{~m}$ long.

At each site-year, the cultivar "InVigor ${ }^{\circledR}$ 5440", a glufosinate-resistant hybrid, was sown in the first to second week of May, with the seed rates calculated based on seed size, germination rate, and field emergence estimates. The uniform plant density treatments were established by adjusting the seeder to the desired seeding rates. The non-uniform treatments were created by the following three steps: (a) seeding for a target plant density of 100 plants per $\mathrm{m}^{2}$, (b) hand-thinning plant rows at the 3-leaf stage as follows: for the non-uniform density treatment of 80 plants per $\mathrm{m}^{2}$, a $20 \mathrm{~cm}$ interval of the plant row was removed from each meter row. Similarly, for the non-uniform density treatments of 60,40 or 20 plants per $\mathrm{m}^{2}$, a 40,60 and $80 \mathrm{~cm}$ interval of the plant row was removed from each meter row, respectively, and (c) checking the hand-thinned plant rows to make sure the target plant density was reached. An example of differences between uniform and non-uniform treatments is shown in Fig. 1. During the growing season, herbicides, fungicides, and insecticides were applied as required (Table 1).

\subsection{Sampling and data collection}

Precipitation and temperature data for each growing season (1 May to 31 August) were obtained from Environment Canada. Three weeks after initial seedling emergence, plant density was counted and recorded from $1 \mathrm{~m}$ of two rows at two spots within each plot. Emergence rate was calculated by following the equation:

Emergence $(\%)=\frac{\text { Plants }_{\text {emerg }}}{\text { Seed }} \times 100$

where Plants emerg $_{\text {was }}$ the average number of plants that emerged per square meter and Seed was the average number of seeds planted per square meter.

At the end of the growing season, plant survival rate was calculated by following the equation:

$\operatorname{Survival}(\%)=\frac{\text { Plants }_{\text {pod }}}{\text { Plants }_{\text {emerg }}} \times 100$

where Plants ${ }_{\text {pod }}$ was the average number of plants with productive pods per square meter and Plants $_{\text {emerg }}$ was the average number of plants emerged per square meter. 
Table 1 Soil chemical properties and herbicide applications in all 16 site-years

\begin{tabular}{|c|c|c|c|c|c|c|c|c|c|}
\hline \multirow[t]{2}{*}{ Soil zone } & \multirow[t]{2}{*}{ Site } & \multirow[t]{2}{*}{ Year } & \multicolumn{4}{|l|}{ Soil property } & \multicolumn{3}{|l|}{ Weed control } \\
\hline & & & $\begin{array}{l}\text { N-P-K-S } \\
\left(\mathrm{kg} \mathrm{ha}^{-1}\right)\end{array}$ & $\begin{array}{l}\text { Texture }(\%) \\
\text { sand:clay:silt }\end{array}$ & $\mathrm{pH}$ & $\begin{array}{l}\text { Organic } \\
\text { matter }(\%)\end{array}$ & $\begin{array}{l}\text { Glufosinate ammonium } \\
\left(\mathrm{kg} \mathrm{ha}^{-1}\right)\end{array}$ & $\begin{array}{l}\text { Clethodim } \\
\left(\mathrm{kg} \mathrm{ha}^{-1}\right)\end{array}$ & $\begin{array}{l}\text { Phosphate } \\
\text { ester surfactant } \\
(\% v / v)\end{array}$ \\
\hline Brown & Swift Current & 2010 & $8.6-35.6-325.7-53.3$ & $31: 50: 18$ & 6.5 & 3 & 0.05 & 0.015 & 0.15 \\
\hline Black/gray & Melfort & 2010 & $11-54-540-6$ & Clay loam & 8.1 & 6.6 & 0.05 & 0.015 & 0.15 \\
\hline Black/gray & Carman & 2010 & $6.7-20-170-69.4$ & $82: 7: 11$ & 5.9 & $-{ }^{\mathrm{a}}$ & 0.05 & 0.015 & 0.15 \\
\hline Black/gray & Lacombe & 2010 & $31-31-503-259$ & $43: 34: 24$ & 7.2 & 9.4 & 0.05 & 0.015 & 0.15 \\
\hline Black/gray & Brandon & 2010 & $6-23-371-5$ & $42: 25: 33$ & 7.5 & 4.6 & 0.05 & 0.015 & 0.15 \\
\hline Brown & Swift Current & 2011 & $8.4-39.2-491.3-53.3$ & $31: 50: 18$ & 6.5 & 3 & 0.05 & 0.015 & 0.15 \\
\hline Black/gray & Carman & 2011 & $23-16-262-89$ & $74: 11: 15$ & 5.5 & 3.9 & 0.05 & 0.015 & 0.15 \\
\hline Black/gray & Morden & 2011 & $11-56-588-21$ & $-{ }^{\mathrm{a}}$ & $-^{\mathrm{a}}$ & $-{ }^{\mathrm{a}}$ & 0.15 & None ${ }^{b}$ & None ${ }^{b}$ \\
\hline Black/gray & Melfort & 2011 & $32-67-600-10$ & Loam & 7.2 & 9.1 & 0.05 & 0.015 & 0.15 \\
\hline Black/gray & Lacombe & 2011 & $44-50-324-32$ & $18: 48: 54$ & 6.8 & 12.3 & 0.05 & 0.015 & 0.15 \\
\hline Black/gray & Indian Head & 2011 & $19.9-16.4-194.5-13.5$ & $-^{\mathrm{a}}$ & $-{ }^{\mathrm{a}}$ & $-{ }^{\mathrm{a}}$ & 0.067 & $0.205^{\mathrm{c}}$ & 0.15 \\
\hline Brown & Swift Current & 2012 & $4.4-28.7-317.5-7.5$ & $31: 50: 18$ & 6.5 & 3 & 0.05 & 0.015 & 0.15 \\
\hline Black/gray & Melfort & 2012 & $20.6-48-540-44$ & Clay loam & 7.1 & 5.9 & 0.05 & 0.015 & 0.15 \\
\hline Black/gray & Carman & 2012 & $29-8-85-29$ & $81: 5: 15$ & 7.1 & - & 0.05 & 0.015 & 0.15 \\
\hline Black/gray & Morden & 2012 & $-{ }^{\mathrm{a}}$ & $-^{\mathrm{a}}$ & $-{ }^{\mathrm{a}}$ & $-{ }^{\mathrm{a}}$ & 0.05 & 0.015 & 0.15 \\
\hline Black/gray & Lacombe & 2012 & $42-28-373-14$ & $22: 42: 36$ & 6.2 & 10.5 & 0.05 & 0.015 & 0.15 \\
\hline
\end{tabular}

${ }^{\text {a }}$ Data were not available

${ }^{\mathrm{b}}$ No application was applied

${ }^{\mathrm{c}}$ Clopyralid was applied at Indian Head 2011 instead of Clethodim

At physiological maturity, four healthy, representative plants were randomly selected from each of the uniform plots, whereas in the non-uniform plots, two plants were taken from the edge of the gap made in the plant row, and the other two plants were taken randomly from within the plant rows. Those plant samples were used to determine the number of fertile pods which contained at least one seed within a pod. Numbers of fertile pods per square meter were the average fertile pods per plant multiplied by plant stands per square meter. At full maturity, plots were machine-harvested, and seeds were cleaned and yield recorded.

\subsection{Data analysis}

Preliminary analyses showed that across the 16 site-years, there were significant treatment $\times$ site-year interactions for most of the variables evaluated in the study, but some of the treatment effects were similar in a number of site-years. To better determine the nature of those interactions in a quantitative manner, the nonmetric multidimensional scaling (NMS) test was used in PCOrd 4.0 to group site-years with different treatment effects. Differences in monthly precipitation, mean, and maximum temperature during the growing season and
Fig. 1 Uniform (left) and nonuniform (right) plant establishment patterns in canola field. Non-uniform plant stands are often caused by different agronomic practices in canola field at western Canada
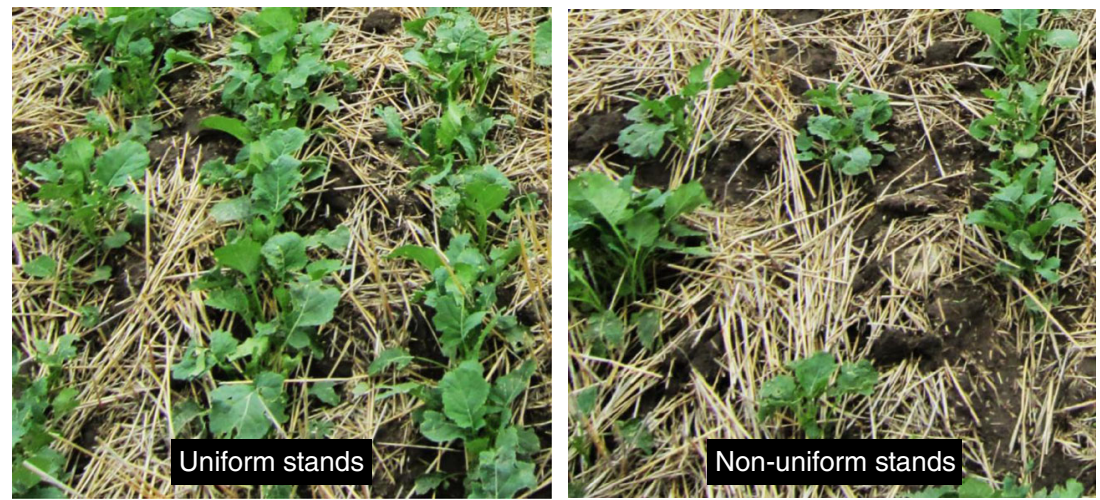
differences in seed yield between the treatments with varying plant densities and uniformities were determined using ANOVA with the functional package "Agricolae" in the R program (R Development Core Team 2009). Linear regression analysis was used to test the relationship between fertile pods per unit area and seed yield using the functional package "Imer" in the R program. The significance of differences between treatment means was assessed using the FisherLSD test, and a threshold of $\alpha=5 \%$ was used to reject or accept the null hypothesis in all analyses.

\section{Results and discussion}

According to the NMS test, those site-years with a similar treatment effect were grouped. As a result, Lacombe 2010, Lacombe 2011, Lacombe 2012, Melfort 2010, and Melfort 2011were grouped as the "high-yielding sites", and the other 11 site-years were grouped as the "lowyielding sites." The NMS test indicated that the treatment effects differed between the two groups $(P=0.0196$, Fig. 2), whereas the treatment effects followed a similar trend within a group. The average seed yield at the highyielding sites was $3,690 \mathrm{~kg} \mathrm{ha}^{-1}$, whereas the average seed yield at the low-yielding sites was $1,780 \mathrm{~kg} \mathrm{ha}^{-1}$.

The grouping concept was also applied to the analysis of seedling emergence rates and plant survival rates as follows: Lacombe 2010, Lacombe 2011, and Lacombe 2012 had the highest emergence rates and the highest survival rates; thus, these three were grouped as "high-emergence and highsurvival rate" sites. Melfort 2010 and Melfort 2011 had low-emergence rates but high-survival rates; thus, the two sites were grouped as "low-emergence and high-survival rate" sites. Swift Current 2011, Indian Head 2011, Morden 2012, Carman 2011, and Carman 2012 had high-emergence rates but low-survival rates; thus, these five site-years were grouped as high-emergence and low-survival rate sites. Finally, Swift Current 2010, Swift Current 2011, Swift Current 2012, Morden 2011, and Melfort 2012 had low-emergence rates with low-survival rates; thus, these were grouped as low-emergence and low-survival rate sites.

\subsection{Uniform planting increased seed yield}

ANOVA revealed a significant relationship between stand uniformity and seed yield (Fig. 3). At both high-yielding $(P=0.0128)$ and low-yielding sites $(P<0.0001)$, uniform plant establishment had higher seed yields compared with non-uniform plant establishment under the same plant density. In particular, at low-yielding sites, uniform stands increased seed yield by $32,21,8$, and $7 \%$ at the plant densities of $20,40,60$, and 80 plants $\mathrm{m}^{-2}$, respectively, compared with the corresponding non-uniform stands. At high-yielding sites, the uniform stands increased seed yields by $21 \%$ compared with non-uniform planting for plant densities lower than 60 plants $\mathrm{m}^{-2}$. Uniformity is important in the production of field crops, largely because resources, often limited in many ago-ecosystems, can be evenly distributed across the plant community and be shared efficiently among individual members. In winter oilseed rape (Brassica napus), non-uniform plant stands decreased seed yield (Hühn 1999) due to increased intraspecific competition and instability of the canola community (Sierts et al. 1987). A non-uniform plant stand can be caused by many factors, such as non-uniform seed spacing, uneven planting depths among seeds, variable frostdamage patterns, variable soil moisture near individual seeds, and uneven soil covering caused by different drill openers. Some practices may cause non-uniform distribution of plant stands, while other practices cause greater intraspecific competition for resources available later in the growing season (Ahmad et al. 2008). Also, uniform plant stands can improve crop yield by increasing the crop's competiveness with weeds. In spring wheat without herbicide application, a uniform stand of wheat plants, reduced weed biomass and resulted in higher wheat yield than a nonuniform stand because the wheat community with uniform stand had better canopy closure (Kristensen et al. 2008). In barley (Hordeum vulgare L.), a uniform stand reduced weed biomass by as much as $30 \%$ compared with a non-uniform stand (Kolb et al. 2010). In some cases, uniform stands can increase crop yield by reducing insect and disease pressure, as non-uniform stands provide more opportunity for pest infestations (Leach et al. 1999).

In the present study, canola yield was also affected by the interaction between uniformity of plant stand and the number of plants per unit area. ANOVA showed that seed yield differences between uniform and non-uniform plant stands at low plant densities was much greater than at high plant densities at both high-yielding and low-yielding sites (Fig. 3). In particular, a yield difference of up to $32 \%$ between uniform and non-uniform treatments was detected when plant density was at or below 60 plants $\mathrm{m}^{-2}$. With overall plant density lower than the ideal, stand uniformity becomes critical for overall yield potential since a uniform stand allows individual plants to use resources more efficiently than plants in a non-uniform stand; this observation is in agreement with previous reports (Angadi et al. 2003). However, with plant density greater than the optimum, interplant competition may increase, leading to increased susceptibility to lodging and disease incidence (Gill and Narang 1993). The optimum canola plant density can modify plant canopy structure to promote synergy of pod formation and seed set, leading to increased 1,000 seed weight and seed yield (Leach et al. 1999). Physiologically, a uniform plant stand at optimum plant density enhances light interception 
Fig. 2 Nonmetric multidimensional scaling test: ordination diagram based on experimental locations (black square), which classified by yield (black up-pointing triangle). Experimental locations grouped at first quadrant are sites with low yield, and experimental locations grouped at third quadrant are sites with high yield. Results indicate significant canola yield differences between high-yielding and low-yielding sites

$(P=0.0196)$

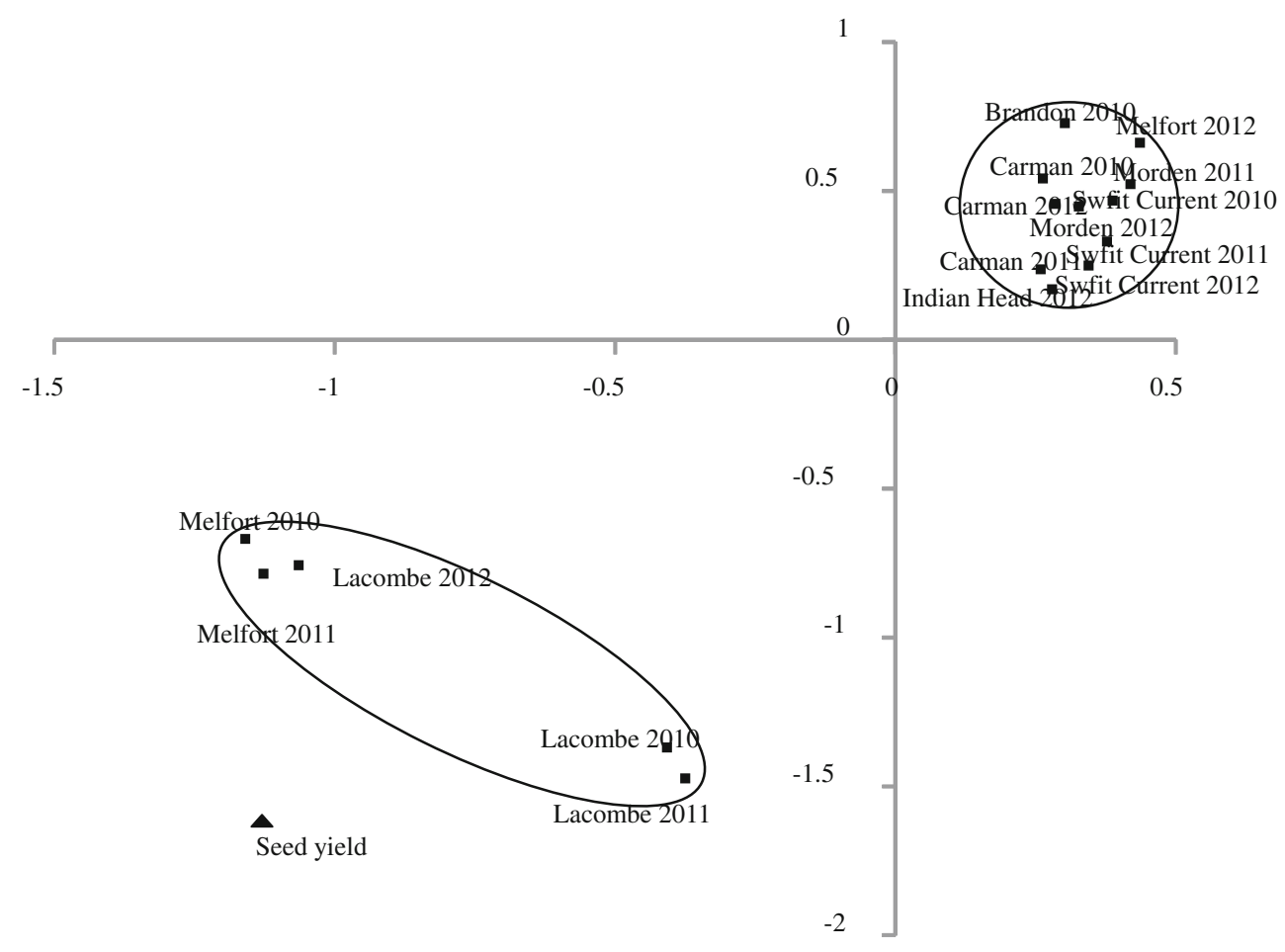

and energy use efficiency, leading to higher photosynthetic rates and therefore higher yield (Velička et al. 2012). These published results support our findings that there was no difference in canola yield between a uniform and a nonuniform plant stand when plant density was higher than 60 plants $\mathrm{m}^{-2}$ at high-yielding sites (Fig. 3).
Fig. 3 Seed yield of canola grown at different densities in uniform versus non-uniform stands at low-yielding and highyielding sites in western Canada. At high-yielding sites (solid line), seed yield under uniform and non-uniform stands are represented by white square and black square, respectively. At low-yielding sites (dotted line), seed yield under uniform and non-uniform stands are represented by white up-pointing triangle and black up-pointing triangle, respectively. Bars are standard error $(n=9)$ of the mean. Significant differences were detected between uniform and non-uniform stands at both highyielding $(P=0.0128)$ and lowyielding $(P<0.0001)$ sites when plant density is lower than 60 plants $\mathrm{m}^{-2}$

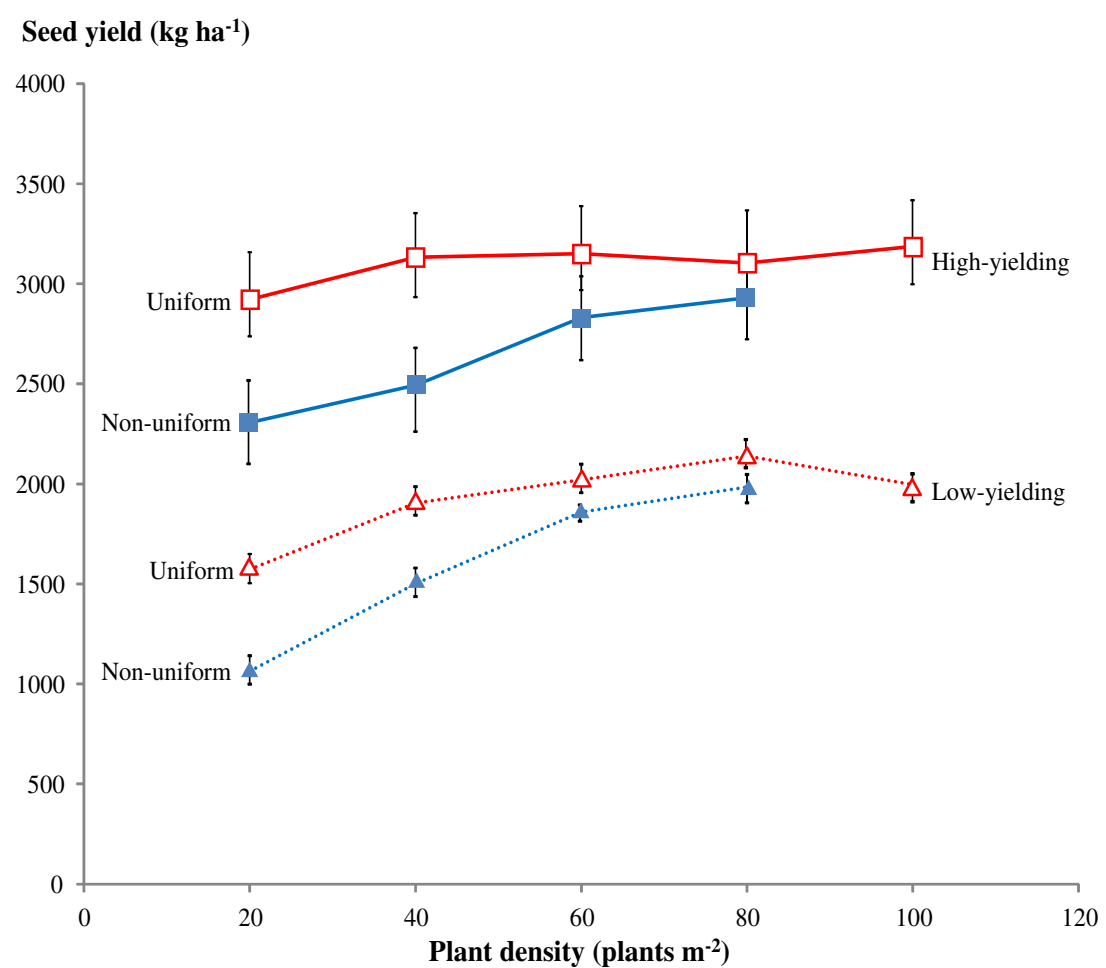


3.2 Uniform planting strengthened the relationship between number of fertile pods and seed yield

A linear relationship between the total number of fertile pods per square meter and seed yield of canola was observed under both uniform $(P=0.002)$ and non-uniform $(P=0.018)$ stands in our study (Fig. 4). In particular, the linear regression showed a greater intercept $(Y=1329.6+0.144 \mathrm{X})$ and higher adjusted $R^{2}(0.74)$ under uniform stands compared with nonuniform stands $\left(Y=742.8+0.191 \mathrm{X}, R^{2}=0.63\right)$. The differences in the intercept of the regression between uniform and nonuniform stands were greater at lower plant densities, indicating greater contribution of fertile pods to canola seed yield with a uniform stand. The number of fertile pods is the most important canola yield component, as reported by previous researchers (Naghizadeh and Hasanzadeh 2012), because more fertile pods per unit area usually lead to higher seed yield in canola (McGregor 1981). Our results further showed that the relationship between fertile pod number and canola seed yield was altered by plant stand uniformity. An evenly distributed plant community alters the distribution of pods within the canopy profile and promotes synchronous pod formation and seed development. As a result, canola seeds have more uniform maturity and possibly with higher oil or protein contents (Leach et al. 1999; Naghizadeh and Hasanzadeh 2012).

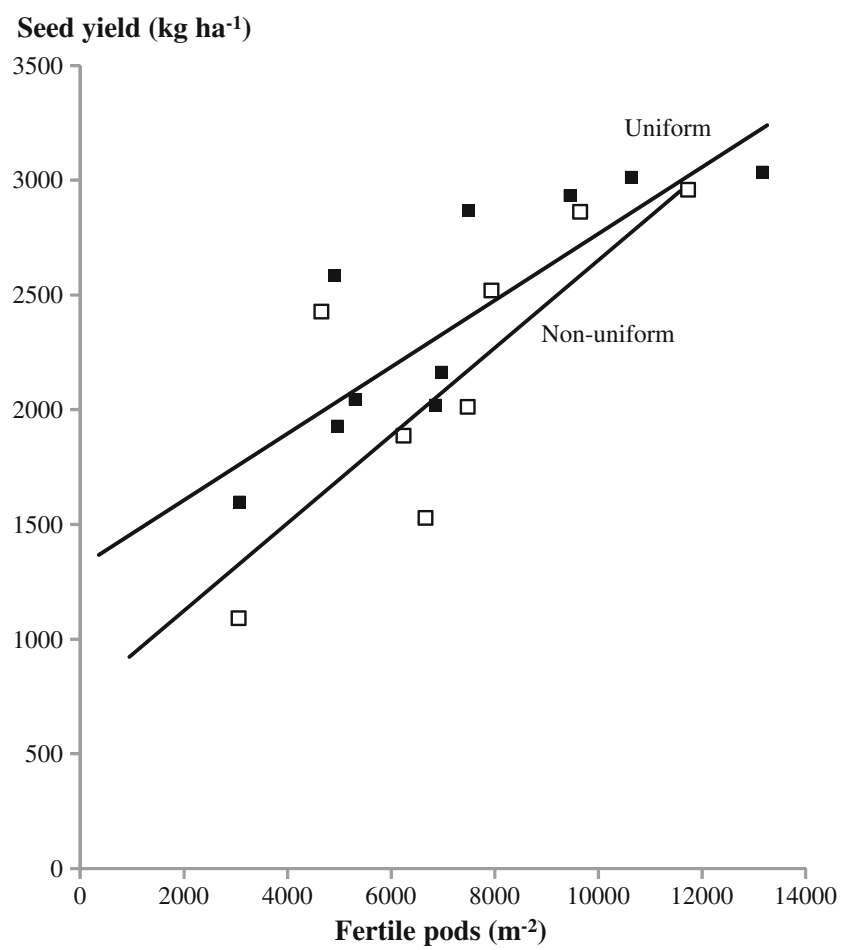

Fig. 4 Linear relationship between yield and number of fertile pods under uniform $\left(Y=1329.6+0.1441 \mathrm{X}, R^{2}=0.74, P=0.002\right.$ represented by black square $)$ and non-uniform $\left(Y=742.8+0.1906 \mathrm{X}, R^{2}=0.63, P=0.018\right.$ represented by white square) patterns in western Canada
In contrast, a non-uniform plant stand increases intraspecific competition within the plant community, which reduces the distribution of optical radiation, causes nutrient deficiencies and limits the development of fertile pods and thus decreasing seed yield (Gill and Narang 1993). Insufficient environmental resources available to some of the individual plants due to intraspecific competition may result in fewer fertile pods because of reduced assimilates distributed to the developing seeds or a shortened seed filling period (Johnson and Hanson 2003). Also, nutrient deficiency caused by interspecific competition may reduce individual seed weight (Kazemeini et al. 2010). Therefore, higher intraspecific competition caused by unevenly distributed plant stands explains the lower intercept of the regression between total number of fertile pods per square meter and seed yield under the nonuniform stands in our study.

\subsection{Canola community establishment and development}

Plant establishment and survival rates differed from site to site (Fig. 5). Actual plant densities were greater than targeted plant densities at high-emergence sites (Fig. 5a, b), and actual densities were near target densities at low-emergence sites (Fig. 5c, d). Previous studies have shown that emergence rate makes a large contribution to canola yield when growth resources are sufficient; a greater rate of emergence usually results in a higher grain fill rate with higher grain yield (Ghassemi-Golezani et al. 2012). Relatively high-emergence rates increase the crop's competitive capabilities with weeds, reduce additional herbicide applications, and decrease selection pressure for herbicide resistance (Harker et al. 2012). However, high-emergence rates did not necessarily result in high-seed yields at all sites. In our study, the average seed yield from the high-emergence and high-survival rate sites (Fig. 5a) was 4,273 $\mathrm{kg} \mathrm{ha}^{-1}$. Canola at the high-emergence but low-survival rate sites (Fig. 5b) was $1,865 \mathrm{~kg} \mathrm{ha}^{-1}$, showing that survival rates are the key for canola seed yield. Previous studies have shown that seed germination rate and seed yield is not necessarily correlated in canola (Ahmadi and Ardekani (2006). Low emergence rates are not always related to lower seed yields (Larsen et al. (1998). Our results show that the development of canola plants at later growth stages can mitigate the negative effects of low emergence rates on seed yield if there are sufficient resources available for plant growth later in the growing season.

At high-yielding sites (average 3,550 $\mathrm{kg} \mathrm{ha}^{-1}$ ), all emerged plants survived through the summer resulting in a nearly $100 \%$ survival rate (Fig. 5a, c). However, at low-yielding sites (average $1,800 \mathrm{~kg} \mathrm{ha}^{-1}$ ), the survival rate was generally lower than $80 \%$ (Fig. 5b, d) even when the emergence rate was high. This indicates that survival rate is more important for canola seed yield than plant emergence, as the emerged seedlings do not necessarily become viable, productive plants later in the growing season. Canola crops with a high rate of survival over the 
Fig. 5 Actual plant density (represented by black square) and survival rate of the emerged plants (represented by white square) under five targeted plant densities $(20,40,60,80$, and 100 plant per $\mathrm{m}^{2}$ ) during the growing season for canola crops grown at a high-emergence rate and highsurvival rate, b high-emergence rate and low-survival rate, $\mathbf{c}$ lowemergence rate and high-survival rate, and $\mathbf{d}$ low-emergence rate and low-survival rate sites in western Canada. Bars are standard error $(n=5)$ of the mean
Actual plant density (plants $\mathbf{m}^{-2}$ ) and survival rate (\%)

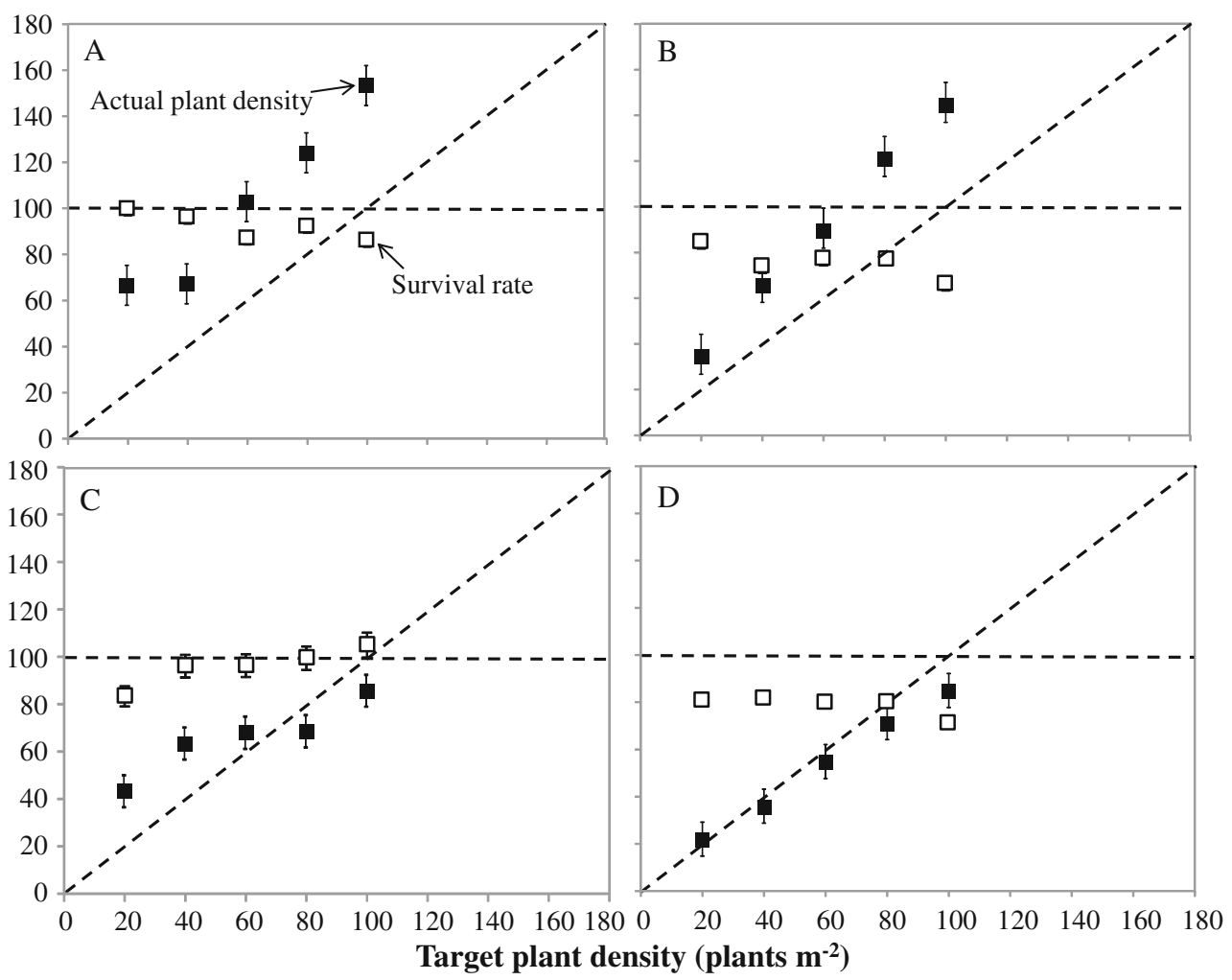

hot summer usually produce high biomass (De Villiers et al. 2006), with increased harvest index and thus higher seed yields (Ghassemi-Golezani et al. 2010).

Our experiments were conducted across the various soilclimatic zones of western Canada; variable environmental factors played an important role on canola plant establishment and development and seed yield. The high-yielding sites received lower $(P<0.0001)$ daily mean temperature and lower daily maximum temperature (18.5 and $24.6{ }^{\circ} \mathrm{C}$, respectively) during the growing season (1 May to 31 August) than the lowyielding sites (20.4 and $26.7^{\circ} \mathrm{C}$, respectively). During the flowering period (mostly from 1 July to 31 July), highyielding sites received lower $(P<0.0001)$ daily mean and maximum temperatures ( 18.5 and $24.6{ }^{\circ} \mathrm{C}$, respectively) than the low-yielding sites (20.0 and $26.5^{\circ} \mathrm{C}$, respectively). Higher temperatures restrict flower initiation and pod formation in canola, limiting canola seed yield as a consequence. Faraji et al. (2008) reported that high temperature during the growing season causes flower/pod abortion and decreases pod number and canola seed yield, which has been confirmed in Saskatchewan by Kutcher et al. (2010). Aksouh-Harradj et al. (2006) found canola plants grown under high temperatures (23 and $28{ }^{\circ} \mathrm{C}$, daily mean and maximum temperatures, respectively) produced fewer and lighter seeds compared with the control (20 and $22{ }^{\circ} \mathrm{C}$, daily mean and maximum temperatures, respectively). Gan et al. (2004) reported that canola plants grown under high temperature (higher than $28^{\circ} \mathrm{C}$ ) produced fewer fertile pods and fewer mature seeds compared with canola plants grown at a moderate temperature $\left(20^{\circ} \mathrm{C}\right)$, especially when these high temperature treatments were imposed during flowering or podding stages. High temperatures also reduce plant height, restrict leaf development (Qaderi et al. 2012), decrease photosynthetic rate, and reduce plant biomass and seed yield (Qaderi and Reid 2009). In addition, the highyielding sites in the present study received more precipitation than the low-yielding sites (67.3 and $45.6 \mathrm{~mm}$, respectively) during the flowering period from early July to late July around 22 days in general. The greater water availability during flowering promotes canola seed set (Tesfamariam et al. 2010) and enhances yield formation (Anastasi et al. 2003). Canola plants tend to form greater numbers of fertile pods when soil water is not limited during the reproductive period (Gan et al. 2004), which leads to higher seed yield (Faraji et al. 2008).

\section{Conclusion}

In the present study, canola stand uniformity had a significant impact on canola productivity, with uniform plant stands increasing seed yield by up to $32 \%$ at the low-yielding sites and $20 \%$ at the high-yielding sites compared to non-uniform 
plant stands. Uniform plant stands optimized the use of available resources, leading to more fertile pods per plant. Plant establishment plays a key role in increasing canola productivity, and yet, our results showed that a higher rate of plant survival to the hot summer had a more significant impact on canola seed yield than seedling emergence rates. For the first time, this comprehensive field experiment, conducted at the multiple sites and years across various climate-soil zones of the Canadian prairies, shows the importance of plant stand uniformity for efficient utilization of environmental resources to enhance pod formation and seed set and increase seed yield. These effects hold true across various climate-soil zones even though the magnitude of the effect varied with environmental conditions. Achieving uniform plant stands may serve as one of the major approaches to close yield gap between the current level of productivity and the potential in canola.

Acknowledgments This research was supported by the Canadian AgriScience Clusters Initiative of the Growing Canadian Agri-Innovations of Agriculture and Agri-Food Canada, Canola Council of Canada, and Saskatchewan Canola Development Commission. We thank Lee Poppy at Swift Current, Colleen Kirkham and Dan Cross at Melfort, Larry Michielsen, Patty Reid, Elizabeth Sroka and Jeenifer Zuidhof at Lacombe, Derek Lewis at Winnipeg, Mark Sandercock at Morden, and Randy Shiplack at Indian Head for their technical assistance and contributions to this work.

\section{References}

Ahmad E, Ghassemzadeh HR, Moghaddam M, Kim KU (2008) Development of a precision seed drill for oilseed rape. Turk $J$ Agric For 32:451-458

Ahmadi SH, Ardekani JN (2006) The effect of water salinity on growth and physiological stages of eight canola (Brassica napus) cultivars. Irrigation Sci 25:11-20. doi:10.1007/s00271-006-0030-3

Aksouh-Harradj NM, Campbell LC, Mailer RJ (2006) Canola response to high and moderately high temperature stresses during seed maturation. Can J Plant Sci 86:967-980. doi:10.4141/P05-130

Al-Barrak KM (2006) Irrigation interval and nitrogen level effects on growth and yield of canola (Brassica napus L.). Sci J King Faisal Univ 7:87-103

Anastasi U, Santonoceto C, Monti M (2003) Growth and yield water status and use of spring and winter rapeseed in relation to time of sowing. Proceedings of the 11th International Rapeseed Congress 3 : 805-807

Angadi SV, Cutforth HW, McConkey BG, Gan Y (2003) Yield adjustment by canola grown at different plant populations under semiarid conditions. Crop Sci 43:1358-1366. doi:10.2135/cropsci2003.1358

Canola Concil of Canada (2012) Canola Performance Trials Results. http://www.canolacouncil.org/publication-resources/printresources/crop-production-resources/grow-canola-resources/ canola-performance-trials-results-2012/. Accessed 27 Sept 2013.

De Villiers RJ, Lamprecht SC, Agenbag GA (2006) Effect of chemical seed treatment on the germination and seedling growth of canola under different soil conditions. S Afr J Plant Soil 23:287-296. doi: 10.1080/02571862.2006.10634767

Faraji A, Latifi N, Soltani A, Rad AHS (2008) Effect of high temperature stress and supplemental irrigation on flower and pod formation in two canola (Brassica napus L.) cultivars at Mediterranean climate. Asian J Plant Sci 7:343-351. doi:10.3923/ajps.2008.343.351
Gan Y, Angadi SV, Cutforth H, Potts D, Angadi VV, McDonald CL (2004) Canola and mustard response to short periods of temperature and water stress at different developmental stages. Can J Plant Sci 84:697-704. doi:10.4141/P03-109

Gan Y, Liang C, Huang G, Malhi SS, Brandt SA, Katepa-Mupondwa F (2012) Carbon footprint of canola and mustard is a function of the rate of $\mathrm{N}$ fertilizer. Int J Life Cycle Assess 17:58-68. doi:10.1007/ s11367-011-0337-z

Ghassemi-Golezani K, Khomari S, Dalil B, Hosseinzadeh-Mahootchy A, Chadordooz-Jeddi A (2010) Effects of seed aging on field performance of winter oilseed rape. J Food Agric Environ 8:175-178

Ghassemi-Golezani K, Sheikhzadeh-Mosaddegh P, Shakiba MR, Mohammadi A, Nasrollahzadeh S (2012) Field performance of differentially matured seeds of oilseed rape cultivars. Res on Crop 13:128-133

Gill MS, Narang RS (1993) Yield analysis in Gobhi Sarson (Brassica napus L.) to plant density and nitrogen. Indian J Agron 38:257-265

Harker KN, O'Donovan JT, Blackshaw RE, Johnson EN, Lafond GP, May WE (2012) Seeding depth and seeding speed effects on no-till canola emergence, maturity, yield and seed quality. Can J Plant Sci 92:795-802. doi:10.4141/cjps2011-189

Hühn M (1999) Experimental results on the effects of nonregular spatial patterns of plants on yield per area. J Agron Crop Sci 182:89-97. doi:10.1046/j.1439-037X.1999.00262.x

Jasso de Rodríguez D, Angulo-Sánchez JL, Díaz-Solís H, RodríguezGarcía R (2002) Rubber yield and guayule populations' attributes in naturally reestablished wild stands in México. Ind Crop Prod 15: 213-220. doi:10.1016/S0926-6690(01)00116-9

Johnson BL, Hanson BK (2003) Row-spacing interactions on spring canola performance in the Northern Great Plains. Agron J 95:703708. doi:10.2134/agronj2003.7030

Kazemeini SA, Edalat M, Shekoofa A, Hamidi R (2010) Effects of nitrogen and plant density on rapeseed (Brassica napus L.) yield and yield components in Southern Iran. J Appl Sci 10:1461-1465. doi:10.3923/jas.2010.1461.1465

Kolb LN, Gallandt ER, Molloy T (2010) Improving weed management in organic spring barley: physical weed control vs. Interspecific competition. Weed Res 50:597-605. doi:10.1111/j.1365-3180.2010.00818.x

Kristensen L, Olsen J, Weiner J (2008) Crop density, sowing pattern, and nitrogen fertilization effects on weed suppression and yield in spring wheat. Weed Sci 56:97-102. doi:10.1614/WS-07-065.1

Kutcher HR, Warland JS, Brandt SA (2010) Temperature and precipitation effects on canola yields in Saskatchewan, Canada. Agr Forest Meteorol 150:161-165. doi:10.1016/j.agrformet.2009.09.011

Larsen SU, Povlsen FV, Eriksen EN, Pedersen HC (1998) The influence of seed vigour on field performance and the evaluation of the applicability of the controlled deterioration vigour test in oil seed rape (Brassica napus) and pea (Pisum sativum). Seed Sci Technol 26:627-641

Larson EJ, Vanderlip RL (1994) Grain sorghum yield response to nonuniform stand reductions. Agron J 86:475-477. doi:10.2134/ agronj1994.00021962008600030003x

Leach JE, Stevenson HJ, Rainbow AJ, Mullen LA (1999) Effects of high plant populations on the growth and yield of winter oilseed rape (Brassica napus). J Agr Sci 132:173-180. doi:10.1017/ S0021859698006091

Legendre P, Fortin M (1989) Spatial pattern and ecological analysis. Vegetatio 80:107-138. doi:10.1007/bf00048036

Liu C, Gan Y, Poppy L (2014) Evaluation of on-farm crop management decisions on canola productivity. Can J Plant Sci 94:131-139. doi: 10.4141/cjps2013-121

McGregor DI (1981) Pattern of flower and pod development in rapeseed. Can J Plant Sci 61:275-282. doi:10.4141/cjps81-040

Naghizadeh M, Hasanzadeh R (2012) Effect of plant density on yield, yield components, oil and protein of canola cultivars in Hajiabad. Adv Environ Biol 6:1000-1005 
Olsen J, Kristensen L, Weiner J, Griepentrog HW (2005) Increased density and spatial uniformity increase weed suppression by spring wheat. Weed Res 45:316-321. doi:10.1111/j.1365-3180.2005. 00456.x

Perry JN, Liebhold AM, Rosenberg MS, Dungan J, Miriti M, Jakomulska A, Citron-Pousty S (2002) Illustrations and guidelines for selecting statistical methods for quantifying spatial pattern in ecological data. Ecography 25:578-600. doi:10.1034/ j.1600-0587.2002.250507.x

Pronk TE, Schieving F, Anten NPR, Werger MJA (2007) Plants that differ in height investment can coexist if they are distributing nonuniformly within an area. Ecol Complex 4:182-191. doi:10.1016/j. ecocom.2007.06.007

Qaderi MM, Kurepin LV, Reid DM (2012) Effects of temperature and watering regime on growth, gas exchange and abscisic acid content of canola (Brassica napus) seedlings. Environ Exp Bot 75:107-113. doi:10.1016/j.envexpbot.2011.09.003

Qaderi MM, Reid DM (2009) Crop responses to elevated carbon dioxide and temperature. In: Climate change and crops. Springer, Berlin, pp $1-19$
Sierts HP, Geisler G, Léon J, Diepenbrock W (1987) Stability of yield components from winter oil-seed rape (Brassica napus L.). J Agron Crop Sci 158:107-113. doi:10.1111/j.1439-037x.1987.tb01153.x

Tesfamariam EH, Annandale JG, Steyn JM (2010) Water stress effects on winter canola growth and yield. Agron J 102:658-666. doi:10.2134/ agronj2008.0043

Tokatlidis IS, Koutroubas SD (2004) A review of maize hybrids' dependence on high plant populations and its implications for crop yield stability. Field Crop Res 88:103-114. doi:10.1016/j.fcr.2003.11.013

Uriarte M, Canham CD, Thompson J, Zimmerman JK (2004) A neighborhood analysis of tree growth and survival in a hurricane-driven tropical forest. Ecol Monogr 74:591-614. doi:10.1890/03-4031

Velička R, Marcinkevičiene A, Kosteckas R, Pupaliene R, Duchovskis P, Brazaityte A (2012) The influence of crop density on the photosynthetic characteristics and productivity of the spring oilseed rape under non-fertilized and fertilized conditions. J Food Agric Environ 10:850-856

Wilson DS, Tilman D (1991) Components of plant competition along an experimental gradient of nitrogen availability. Ecology 72:1050 1065 